\title{
HUBUNGAN TINGKAT KEPUASAN PASIEN MISKIN PENGGUNA BPJS TERHADAP KINERJA PELAYANAN KESEHATAN DI RSUD ULIN BANJARMASIN TAHUN 2016
}

\author{
Fakhsiannor \\ FISIP, Universitas Islam Kalimantan MAB (UNISKA) Banjarmasin \\ Email: fakhsiannor@gmail.com
}

\begin{abstract}
The hospital is as a health service that functions primarily organizes health effort that is healing and recovery of patients, which provides services to the public regardless of social kulturnya. In support of the implementation of public health assurance program (BPJS) hospital has a very important role in providing services to the poor. In preliminary studies to 20 respondents, there were 12 respondents (60\%) declare non puasan and 8 respondents (40\%) expressed their satisfaction with the performance of medical services at the hospital Ulin Banjarmasin. This research aims to find out the level of patient satisfaction Guarantee public health with the performance of the health service in general hospital Ulin Banjarmasin in Central Kalimantan, covering the five dimensions of service i.e. reliability, responsiveness, assurance, empathy and physical evidence. This type of research Survey with Analytic design Crossectional. Population studies are all patient health care Community who visited the Hospital General Ulin Banjarmasin in during the period of research, whereas samples taken by Accidental Sampling, as many as 93 respondents. The collection of data through interviews using questionnaire. The results showed that of the 5 variables examined is reliability, responsiveness, empathy and reassurance, physical evidence against the performance of health service officers at the Hospital found 5 related variables are meaningful.
\end{abstract}

Keywords: satisfaction, health service performance

\section{PENDAHULUAN}

Rumah Sakit sebagai salah satu fasilitas pelayanan kesehatan memiliki peran yang sangat strategis dalam upaya mempercepat peningkatan derajat kesehatan masyarakat Indonesia. Peran strategis ini di peroleh karena Rumah Sakit adalah fasilitas kesehatan yang padat teknologi dan padat pakar (Aditama, 2003).

Pengetahuan masyarakat yang semakin meningkat, akan berpengaruh terhadap meningkatnya tuntutan masyarakat akan mutu pelayanan kesehatan, di samping itu dalam menyelenggarakan pelayanan kesehatan Rumah Sakit juga banyak disoroti oleh masyarakat mengenai kinerja tenaga-tenaga kesehatan selain masyarakat juga mengkritisi berbagai aspek yang terdapat dalam pelayanan kesehatan terutama pelayanan keperawatan. Di Rumah Sakit, sumber daya manusia terbanyak yang berinteraksi secara langsung dengan pasien adalah perawat, sehingga kualitas pelayanan yang dilaksanakan oleh perawat dapat dinilai sebagai indikator baik apa buruknya kualitas pelayanan di Rumah Sakit.

Sebagai penerima jasa pelayanan kesehatan BPJS, keluarga peserta seringkali mengeluh kurang puas dengan pelayanan kesehatan yang diterimanya. Mereka menganggap bahwa pasien yang menjadi peserta BPJS Kesehatan masyarakat miskin mendapat pelayanan dan perlakuan yang berbeda dengan pasien lain di beberapa Rumah Sakit, baik yang di rawat maupun yang hanya berobat.

Dari studi yang dilakukan peneliti pada tanggal 06 Desember 2016 melalui hasil observasi dan wawancara yang peneliti lakukan pada beberapa pasien miskin pengguna layanan BPJS, sebagian besar menyampaikan berbagai keluhan mengenai layanan kesehatan BPJS, 6 
dari 10 orang pasien miskin pengguna BPJS mengatakan bahwa pelayanan yang diterima tidak sama dengan pelayanan yang diberikan ke pasien lain yang bukan pengguna layanan kesehatan BPJS, pasien miskin pengguna BPJS mendapat tempat yang terbatas, alur administrasi yang terkesan berbelit-belit.

Untuk meningkatkan pelayanan kesehatan pada pasien miskin pengguna BPJS kesehatan dapat dilakukan berbagai upaya seperti mempermudah alur pengurusan persyaratan pasien BPJS, pembagian tugas perawat dalam perawatan kepada pasien, melengkapi sarana dan prasarana rawat inap BPJS. Akan tetapi upaya tersebut belum dapat mengurangi persepsi pasien terhadap kualitas pelayanan pasien miskin pengguna BPJS di RSUD Ulin Banjarmasin.

\section{METODE PENELITIAN}

Desain penelitian ini merupakan penelitian survey analitik dengan menggunakan rancangan/desain analitik korelasi atau Cross Sectional Study. Sampel pada penelitian ini adalah pasien miskin pengguna BPJS yang rawat inap di ruang bangsal RSUD Ulin Banjarmasin. Sampel pada penelitian ini menggunakan metode Aksidental Sampling yaitu teknik penentuan sampel yang dilakukan dengan kebetulan bertemu terhadap pasien miskin pengguna BPJS yang rawat inap di ruang bangsal RSUD Ulin Banjarmasin selama peneliti melakukan penelitian yaitu dalam waktu satu minggu. Istrumen yang digunakan melalui kuesioner kuliatas pelayanan kesehatan meliputi dimensi kehandalan, dimensi daya tanggap, dimensi jaminan, dimensi bukti langsung dan dimensi empati.

Data primer diperoleh langsung dari responden atau subjek penelitian dengan menggunakan lembar kuesioner tentang kualitas pelayanan kesehatan pada pasien miskin pengguna BPJS. Data dikumpulkan langsung melalui kuesioner yang diberikan kepada responden untuk diisi dengan didampingi oleh peneliti.

Data dikumpulkan diolah dan dianalisis secara deskriptif dengan menggunakan tabel disribusi frekuensi dan diuraikan dalam bentuk prosentase secara narasi. Selanjutnya diinterpretasikan oleh peneliti dengan merujuk teori-teori yang mendukung dalam penelitian ini.

\section{HASIL DAN PEMBAHASAN}

Hasil penelitian menunjukkan bahwa dari 93 responden berdasarkan umur, pasien miskin pengguna BPJS yang berkunjung ke RSUD Ulin Banjarmasin lebih banyak berusia $>30$ tahun yaitu $(57,0 \%)$, kemudian berusia $>40$ tahun 26 responden $(28.0 \%)$ usia $>20$ tahun 10 responden $(10,8 \%)$, dan terkecil berusia 50 tahun sebanyak 4 responden $(4.3 \%)$.

Responden yang melakukan penilaian terhadap Kehandalan (Reliability) terhadap kinerja dengan kepuasan pasien sebanyak 64 responden $(68,8 \%)$ puas, sedangkan 29 responden $(31,2 \%)$ responden menyatakan ketidak puas. Hasil analisis diperoleh nilai $p$ value $=0.000$, ini berari ada hubungan yang bermakna antara tingkat kepuasan pasien dengan kehandalan kinerja pelayanan kesehatan di RSUD Ulin Banjarmasin.

Menurut Zeithaml, M.T. Bitner dan Adrian Palmer dalam (Irine : 2008) beberapa hal yang menjadi penyebab tingginya penilaian kehandalan petugas kesehatan adalah pelayanan pemeriksaan, pengobatan dan perawatan yang cepat, jadwal pelayanan dijalankan dengan tepat dan prosedur pelayanan yang tidak berbelit sehingga pasien tidak dikecewakan. Sedangkan menurut Parasuraman, 1985 (dalam Irine : 2008) yang dapat menentukan kualitas pelayanan adalah perbandingan antara harapan dengan memberikan pelayanan sesuai dengan dijanjikan, bisa diandalkan dengan akurat yang meliputi kecepatan pelayanan tepat waktu, ketepatan pelayanan dan kelancaran pelayanan.

Penilaian terhadap Daya Tanggap (Responsiveness) terhadap kinerja dengan kepuasan pasien ada 68 responden $(73,1 \%)$ responden puas, sedang 25 responden $(26,9 \%)$ responden menyatakan tidak puas. Hasil analisis diperoleh nilai $p$ value $=0.000$, ini berarti ada hubungan yang bermakna antara tingkat kepuasan pasien dengan ketanggapan kinerja pelayanan kesehatan di RSUD Ulin Banjarmasin.

Dalam hal daya tanggap sudah banyak 
kelebihan yang diberikan oleh petugas kesehatan di di RSUD Ulin Banjarmasin yaitu petugas mempunyai kemampuan untuk membantu pelanggan dan memberikan jasa dengan tanggap, seperti petugas memberikan informasi yang jelas dan mudah dimengerti.

Tanggapan pelanggan dalam hal ini pasien peserta BPJS Kesehatan masyarakat miskin terhadap kinerja pelayanan kesehatan yang diterima, baik puas atau tidak puas perlu juga diukur, dievaluasi, dan ditindaklanjuti. Data mengenai kepuasan pelanggan/pasien dapat diperoleh dari berbagai sumber, antara lain dengan surveilens kepuasan pelanggan.

Penilaian terhadap Jaminan (Assurance) terhadap kinerja dengan kepuasan pasien sebanyak 69 responden (74.2\%) puas, sedangkan 24 responden $(25,8 \%)$ menyatakan tidak puas. Hasil analisis diperoleh nilai $p$ value $=0.000$, ini berarti ada hubungan yang bermakna antara pasien di RSUD Ulin Banjarmasin.

Menurut Azwar (1995) terbinanya hubungan antara petugas kesehatan dan pasien secara baik adalah salah satu dari kewajiban etika profesi. Untuk dapat terselenggaranya pelayanan kesehatan yang bermutu, hubungan antara petugas kesehatan dan pasien yang baik ini harus dipertahankan.

Penilaian terhadap Empati (Empathy) terhadap kinerja dengan kepuasan pasien ada 69 responden $(74.2 \%)$ puas, sedangkan 24 responden $(25.8 \%)$ menyatakan tidak puas. Hasil analisis diperoleh nilai $p$ value $=0.002$ berarti ada hubungan yang bermakna antara tingkat kepuasan di RSUD Ulin Banjarmasin.

Empati ini merupakan syarat untuk memenuhi kebutuhan pasien dengan kepedulian, perhatian secara individu kepada pasien yaitu dalam bentuk keramahan. Hal ini sesuai dengan teori menurut Timothy (1999) Pelanggan adalah orang yang harus diperlakukan dengan rasa hormat, diberi perhatian besar, dibantu dengan menunjukan minat terhadapnya, diberi saran dalam penyelesaian persoalannya, diperlakukan dengan hati-hati penuh pertimbangan (Irine, 2008).

Kalau dihubungkan dengan pendapat dan teori diatas kaitan dengan kepuasan pasien peserta BPJS Kesehatan dalam melakukan pengobatan di di RSUD Ulin Banjarmasin tidak terlepas dari kepedulian petugas terhadap keluhan pelanggan, pelayanan kepada semua pelanggan tanpa memandang status, dimana empati merupakan faktor penting dalam hal kepuasan pasien.

Penilaian terhadap Bukti Fisik (Tangibels) kinerja dengan kepuasan pasien sebanyak 62 responden $(66.7 \%)$ puas dan 31 responden $(33,3 \%)$ menyatakan tidak puas. Hasil analisis diperoleh nilai $p$ value $=0.000$, ini berarti ada hubungan yang bermakna antara tingkat kepuasan pasien dengan Bukti Fisik (Tangibles) terhadap kinerja pelayanan kesehatan di RSUD Ulin Banjarmasin.

Menurut Parasuraman, 1985 (Irine, 2008) keberwujudan merupakan perbandingan antara harapan dengan kenyataan terhadap bukti langsung berupa keberwujudan seperti kebersihan lokasi tempat pelayanan, fasilitas tempat layanan dan kerapian petugas kesehatan.

Kemudian penilaian terhadap Kinerja Pelayanan Kesehatan di RSUD Ulin Banjarmasin, ternyata yang menilai puas sebanyak 68 responden $(73,1 \%)$, sedangkan responden yang tidak puas sebanyak 25 responden $(26,9 \%)$.

Kinerja merupakan hasil pekerjaan yang mempunyai hubungan kuat dengan tujuan strategi organisasi, kepuasan konsumen, dan memberikan kontribusi pada ekonomi (Amstrong dan Baron, 1998 : 15). Dengan demikian, kinerja adalah tentang melakukan pekerjaan dan hasil yang dicapai dari pekerjaan tersebut. Kinerja adalah tentang apa yang dikerjakan dan bagaimana cara mengerjakannya.

\section{KESIMPULAN}

Ada hubungan antara Kehandalan (Reliability) terhadap kinerja pelayanan kesehatan di RSUD Ulin Banjarmasin diperoleh nilai $p$ value $=0.000$, Daya Tanggap (Responsiveness) diperoleh nilai $\mathrm{p}$ value $=$ 0.000. Jaminan (Assurance) diperoleh nilai $p$ value $=0.000$. Empati (Empathy) diperoleh nilai $p$ value $=0.002$. Bukti Fisik (Tangibels) diperoleh nilai $p$ value $=0.000$.

Sedang penilaian terahdap kinerja pelayanan kesehatan yang diberikan petugas pasien peserta BPJS untuk masyarakat miskin di 
RSUD Ulin Banjarmasin yang menyatakan puas sebanyak 68 responden $(73,1 \%)$, sedangkan yang tidak puas sebanyak 25 responden $(26,9$ $\%)$.

\section{REFERENSI}

Anonim, Laporan Jumlah Kunjungan Pasien Jamkesmas RSUD Ulin Banjarmasin, Tahun 2015.

Anonim, Laporan Register Bulanan Pasien Jamkesmas, RSUD Ulin Banjarmasin, Tahun 2015.

Azwar, Azrul, 1996. Menjaga Mutu Pelayanan Kesehatan. Edisi Kedua, Jakarta .

Departemen Kesehatan RI, 2011. Pedoman Juknis Jamkesmas dan Jamkesda, Dirjend. Binkesmas, Jakarta.

Departemen Kesehatan RI, 2003. Pedoman Pemantauan Berkala Kepuasan Pengguna Jasa Puskesmas, Dirjend. Binkesmas, Jakarta.

Notoatmojo Soekidjo, 2007. Kesehatan Masyarakat Ilmu dan Seni, Rineka Cipta, Jakarta.

Notoatmojo Soekidjo, Metode Penelitian Kesehatan, Edisi Revisi. Rineka Cipta, Jakarta.

Pohan, S. Imbalo 2002. Jaminan Mutu Layanan Kesehatan. Jakarta: Penerbit Buku Kedokteran.

Supranto J, 2006. Pengukuran Tingkat Kepuasan Pelanggan, Rineka Cipta Jakarta.

Tjiptono. F dan Chandra. G, 2011. Service, Quality dan Satisfaction, Andi, Yogyakarta.

Wibowo, 2007. Manajemen Kinerja, PT. Raja Grafindo Persada. 